\title{
Association Between GCA and Per Se Performance of Parents and Hybrids for Grain Yield, its Attributing Traits and Late Wilt Disease (Harpophora maydis) Resistance in Maize (Zea mays L.)
}

\author{
Mahesh Biradar*, E. Gangappa, S. Ramesh, P. Roopa Sowjanya, \\ N. C. Sunitha, Gazala Parveen, H. H. Sowmya and K. Suma
}

Department of Genetics and Plant Breeding, UAS, GKVK, Bengaluru - 560065, India

*Corresponding author

\section{A B S T R A C T}

\begin{tabular}{|l|}
\hline K e y w o r d s \\
LWD, gca, $s c a$, \\
Maize, Inbred
\end{tabular}

Initial evaluation of in breds for general combining ability $(g c a)$ enables plant breeders to discard undesirable ones and identify those that are potential for the production of superior hybrids. In this context, 11 parental in breds which are contrasting for Late Wilt Disease (LWD) reaction (4 LWD resistant and 7 LWD susceptible) and yielding ability were selected and were evaluated for their gca related to grain yield plant ${ }^{-1}$, its attributing traits and reaction to LWD infection. The analysis of variance revealed significant differences among the inbred lines for their per se performance as well as their gca. Similarly, the hybrids differed significantly for per se performance and their specific combining ability (sca) effects for all the traits. The non-significant correlation between per se performance and gca effects suggested that per se performance of inbred lines is not a good indicator of their gca effects for any of the traits studied including reaction to LWD infection. However, significant positive and fairly high magnitude of correlation between per se performance of hybrids and sum of parental gca effects for all the traits under study including reaction to LWD infection indicating that parental $g c a$ effect is good indicator of per se performance of hybrids. hence, parents having higher gca effects are expected to give good performing hybrids.

\section{Introduction}

Maize (Zea mays L.) is an important cereal crop in the world and a primary staple food in many developing countries that provides food, feed, fuel and other industrial raw materials. But now a days it is affected by many biotic and abiotic stresses, among them biotic stresses are predominant, hence, resistance breeding for LWD is at most important. In maize single cross hybrids are the major cultivar types used for commercial production in most parts of the world. Hybrids have played a vital role in increasing the area and productivity of maize.

Superior hybrids are produced if the parents involved have good general combining ability (gca), which is the relative ability of a genotype to transmit its genes with additive effects to its progeny. The concept of $g c a$ (Sprague \&Tatum, 1942) is a widely accepted 
criteria for assessing the inbreds for their use as parents in the development of heterotic hybrids. Testing of inbreds for their $\mathrm{gca}$ effects enables plant breeders to discard most of the undesirable inbreds (low per se performance and LWD susceptible) and allows greater expenditure of resources on most promising ones and identifies those that are desirable for the production of superior hybrids (Bernardo, 2010; Ali et al., 2011; AiZhi\& Zheng, 2012; Fasahat et al., 2016; Hosana et al., 2015).

Apart from providing an objective criterion for choosing parents, gca also provides useful clues about mode of action of genes controlling economically important traits. Another utility of $g c a$ of the parents is their predictive power of hybrid per se performance in the absence of significant hybrid specific combining ability (sca) effects. Under these premises, an investigation was undertaken to assess the relationship between gca and per se performance of parents and hybrids of maize.

\section{Materials and Methods}

\section{Basic material}

Based on prior evaluation of 300 inbred lines of maize (Aruna et al., 2018), 11 were selected based on LWD reaction and grain yield plant ${ }^{-1}$ and they constituted the basic genetic material.

\section{Development and field evaluation of experimental material}

These 11 inbreds were crossed following full diallel mating design (Hayman, 1954) to develop 110 single cross hybrids ( $\mathrm{SCH}$ ) during kharif 2018 at the experimental plots of the Department of Genetics and Plant Breeding (GPB), University of Agricultural Sciences (UAS), Gandhi Krishi Vignana
Kendra (GKVK), Bengaluru. The resultant $110 \mathrm{SCH}$, their parents and five checks viz., Hema and Nithyashree for yield evaluation and P3501 and NK 6240 LWD screening constituted the experimental material and were evaluated following simple lattice design in two different sets of experiments with two replications. Each entry was sown in one row of $3 \mathrm{~m}$ length with a spacing of $0.6 \mathrm{~m}$ $\times 0.3 \mathrm{~m}$. All the recommended package of practices was followed to raise a healthy crop.

\section{Sampling of plants and data recorded}

Data were recorded on five randomly selected competent plants in both the replications, on each hybrid, parent and checks for LWD reaction, grain yield plant ${ }^{-1}$ and its attributing traits.

\section{Statistical analysis}

Replication wise mean data of hybrids, parents and checks was used for statistical analysis. Data of $F_{1}$ hybrids were subjected to combining ability analysis following diallel model (Hayman, 1954; Griffing, 1956). The gca effects of 11 lines were estimated and their statistical significance was examined using ' $t$ ' test.

\section{Relationship of gca effects of inbred lines with their per se performance}

Relationship between per se performance of 11 inbred lines and their gca effects were determined by estimating Spearman's Rank Correlation Coefficient for all the traits.

Where,

$$
r=1-\frac{6 \mathrm{Ed}^{2}}{\mathrm{n}\left(\mathrm{n}^{2}-1\right)}
$$

$\mathrm{r}=$ Spearman's Rank Correlation Coefficient

$\mathrm{d}=$ Differences in ranks given to per se performance of hybrids and sum of 
their parental gca effects based on magnitude and direction

$\mathrm{n}=\quad$ Number of pairs of values

Higher magnitude of positive significant and non-significant correlation indicates good and poor predictive power of per se performance, respectively.

\section{Relationship of hybrid per se performance with sum of parental $\mathrm{gca}$ effects}

Pearson's Correlation Coefficients between hybrids per se performance and sum of $\mathrm{gca}$ effects of their parents were estimated for all traits (Schrag et al., 2009) including LWD reaction. Significant correlation with fairly high coefficients of correlation and determination was interpreted as high predictability of hybrid per se performance based on their sum of parental gca effects.

\section{Results and Discussion}

\section{Analysis of variance (ANOVA)}

Simple Lattice design ANOVA revealed there is significant difference among the hybrids for all the traits under study including LWD disease reaction indicating diverse nature of the crosses used in the study, Hence the data is further considered for diallel analysis. Diallel ANOVA indicated significant differences among single cross hybrids for all the traits (Table 1). Significant mean squares due to inbreds and hybrids suggested substantial variability for $g c a$ effects of inbreds and sca effects of their crosses for all the traits including LWD reaction. Significant variances among the crosses could be attributed to greater diversity between inbreds for the traits considered. The mean squares attributable to inbreds and crosses for all the traits indicated greater contribution of the inbreds towards total variation among the hybrids (Kanagarasu et al., 2010).

\section{General combining ability of inbred lines}

The practical phase of maize hybrid breeding is identification of potential inbred lines with high gca for use as parents for developing hybrids that are superior to existing ones (ElHosary, 2014). Identification of such elite inbred lines is the major strategy adopted by most commercial plant breeders to maximize genetic gain per unit time and resources.

This assumption is based on the reports that gca is controlled by additive effect genes which control the inheritance of phenotypes that are fixable (Ai-Zhi\& Zheng, 2012). In the present study, the inbred lines differed widely for their gca effects for all the quantitative traits including for LWD reaction.

The differences in gca effects of the inbreds are attributable to differences in frequencies of genes that are transmitted to the progeny with the additive effects (Falconer \& Mackay, 1996). The differences in gene frequencies among the inbreds suggest their significant genotypic differences, thus justifying their selection for the present study.

Different inbred lines were desirable general combiners in both direction and magnitude for different traits (Table 2). Thus, no single line was a desirable combiner for all the seven traits. For instance, inbreds such as 97B and MAI-345 were desirable general combiners for ear circumference, 100 grain weight and grain yield plant ${ }^{-1}$.

However, inbred line 40458 is best general combiner for kernel rows ear ${ }^{-1}$ and kernels row $^{-1}$. Inbred lines MAI-21 and MAI-345 were found to be good general combiners for LWD reaction. It should however be noted that the estimates of $\mathrm{gca}$ effects of 11 inbred lines are relative to and are dependent on particular set of parents included in the experiment (Fasahat et al., 2016). 
Table. 1 ANOVA of $11 \times 11$ full diallel crosses and their parents for grain yield its component traits and reaction to LWD infection in maize

\begin{tabular}{|c|c|c|c|c|c|c|c|c|}
\hline \multirow{2}{*}{$\begin{array}{l}\text { Source of } \\
\text { variation }\end{array}$} & \multirow{2}{*}{$\begin{array}{c}\text { Degrees } \\
\text { of } \\
\text { freedom }\end{array}$} & \multicolumn{7}{|c|}{ Mean sum of squares } \\
\hline & & $\begin{array}{c}\text { Ear } \\
\text { length } \\
(\mathrm{cm})\end{array}$ & $\begin{array}{c}\text { Ear } \\
\text { circumference } \\
(\mathrm{cm})\end{array}$ & $\begin{array}{l}\text { Kernel } \\
\text { rows } \\
\text { cob }^{-1}\end{array}$ & $\begin{array}{c}\text { Kernels } \\
\text { row }^{-1}\end{array}$ & $\begin{array}{l}100 \text { grain } \\
\text { weight }(g)\end{array}$ & $\begin{array}{l}\text { Grain yield } \\
\text { plant }^{-1}(\mathrm{~g})\end{array}$ & $\begin{array}{l}\text { Response to } \\
\text { LWD } \\
\text { reaction }\end{array}$ \\
\hline Replication & 1 & 0.86 & 1.87 & 0.14 & 0.06 & 28.06 & 986.72 & 0.15 \\
\hline $\begin{array}{l}\text { Inbreds + } \\
\text { Hybrids }\end{array}$ & 120 & $7.15 * * *$ & $1.42 * * *$ & $2.09 * * *$ & $56.22 *$ & $34.15 * * *$ & $1584.06 * * *$ & $1.33 * * *$ \\
\hline Inbreds & 10 & $14.20 * * *$ & $4.48 * * *$ & $5.69 * * *$ & $132.80 * * *$ & $18.70 * *$ & $1265.25 * * *$ & $3.43 * * *$ \\
\hline Hybrids & 109 & $5.63 * * *$ & $1.15 * * *$ & $1.63 * *$ & $37.97 * * *$ & $25.24 * * *$ & $928.32 * * *$ & $1.12 * * *$ \\
\hline $\begin{array}{l}\text { Indreds } \\
\text { Vs. } \\
\text { Hybrids }\end{array}$ & 1 & $102.10 * * *$ & 0.01 & $17.04 * * *$ & $1279.17 * * *$ & $1159.76 * * *$ & $76248.34 * * *$ & $2.88 *$ \\
\hline $\begin{array}{l}\text { Straight } \\
\text { crosses }\end{array}$ & 54 & $6.30 * * *$ & $1.26 * * *$ & $1.70 * *$ & $41.25 * * *$ & $23.58 * * *$ & $1112.79 * * *$ & $0.99 * *$ \\
\hline $\begin{array}{l}\text { Reciprocal } \\
\text { crosses }\end{array}$ & 54 & $5.06 * * *$ & $1.06 * * *$ & $1.58 * *$ & $35.38 * * *$ & $27.31 * * *$ & $754.21 * * *$ & $1.25 * * *$ \\
\hline $\begin{array}{l}\text { Straight vs. } \\
\text { Reciprocal } \\
\text { crosses }\end{array}$ & 1 & 0.64 & 0.00 & 0.01 & 1.13 & 3.31 & 369.33 & 1.39 \\
\hline Error & 120 & 1.81 & 0.40 & 0.93 & 12.87 & 6.99 & 110.70 & 0.52 \\
\hline Total & 241 & 4.46 & 0.91 & 1.50 & 34.40 & 20.67 & 849.91 & 0.92 \\
\hline GCA & 10 & $10.57 * * *$ & $1.45 * * *$ & $3.52 * * *$ & $60.04 * * *$ & $23.86 * * *$ & $1175.29 * * *$ & $1.85 * * *$ \\
\hline SCA & 55 & $3.56 * * *$ & $0.63 * * *$ & $0.81 * *$ & $31.11 * * *$ & $18.37 * * *$ & $1115.51 * * *$ & $0.58 * * *$ \\
\hline Error & 120 & 0.90 & 0.19 & 0.46 & 6.43 & 3.49 & 55.35 & 0.25 \\
\hline
\end{tabular}

*Significant at $\mathrm{P}=0.05$; ** Significant at $\mathrm{P}=0.01 ; * * *$ Significant at $\mathrm{P}=0.001$ 
Table.2 Estimates of general combining ability effects of 11 parents for grain yield, its component traits and reaction to LWD infection in maize

\begin{tabular}{|c|c|c|c|c|c|c|c|}
\hline $\begin{array}{l}\text { Parental } \\
\text { lines }\end{array}$ & $\begin{array}{l}\text { Ear } \\
\text { length } \\
(\mathrm{cm})\end{array}$ & $\begin{array}{c}\text { Ear } \\
\text { circumference } \\
(\mathrm{cm})\end{array}$ & $\begin{array}{c}\text { Kernel } \\
\text { rows } \\
\text { ear }^{-1}\end{array}$ & $\begin{array}{c}\text { Kernels } \\
\text { row }^{-1}\end{array}$ & $\begin{array}{l}100 \text { grain } \\
\text { weight } \\
\text { (g) }\end{array}$ & $\begin{array}{c}\text { Grain } \\
\text { yield } \\
\text { plant }^{-1}(\mathrm{~g})\end{array}$ & $\begin{array}{l}\text { Response } \\
\text { to LWD } \\
\text { reaction }\end{array}$ \\
\hline 97B & 0.18 & $0.57 * * *$ & 0.19 & $1.96 * * *$ & $1.23 * *$ & $15.82 * * *$ & -0.03 \\
\hline MQ43 & $-0.67 * * *$ & $-0.22 *$ & 0.13 & $-2.56 * * *$ & -0.68 & $-13.30 * * *$ & $0.22 *$ \\
\hline MAI-21 & 0.10 & 0.12 & $0.44 * *$ & -0.98 & 0.06 & $4.22 * *$ & $-0.48 * * *$ \\
\hline MAI-740 & $-1.39 * * *$ & $0.35 * * *$ & -0.18 & $-3.80 * * *$ & 0.20 & $-5.84 * * *$ & $0.65 * * *$ \\
\hline 70 & $-0.71 * * *$ & $0.31 * * *$ & 0.19 & $-1.51 * *$ & $1.20 * *$ & 1.63 & -0.12 \\
\hline 59 & $-0.86 * * *$ & $-0.18 *$ & $-0.97 * * *$ & $-1.63 * *$ & $1.74 * * *$ & $-5.66 * * *$ & 0.13 \\
\hline 40297 & $1.27 * * *$ & 0.12 & $-0.74 * * *$ & 0.93 & 0.36 & -0.26 & $0.27 *$ \\
\hline 40458 & $1.83 * * *$ & $-0.64 * * *$ & $0.51 * * *$ & $4.44 * * *$ & $-2.44 * * *$ & $4.10 * *$ & -0.15 \\
\hline 18758 & $0.55^{* *}$ & $-0.40 * * *$ & 0.14 & $2.51 * * *$ & $-2.80 * * *$ & $-10.18 * * *$ & -0.004 \\
\hline MAI-334 & $-0.49 *$ & $-0.31 * * *$ & -0.12 & -0.17 & -0.44 & $-3.14 *$ & -0.16 \\
\hline MAI-345 & 0.19 & $0.28 * *$ & $0.39 * *$ & 0.81 & $1.56^{* * * *}$ & $12.61 * * *$ & $-0.33 * *$ \\
\hline $\mathbf{G}_{\mathbf{i}}-\mathbf{G}_{\mathbf{j}} @ \mathbf{5 \%}$ & $0.6390 * *$ & $0.2996 * *$ & $0.4575 * *$ & $1.7043 * *$ & $1.2563 * *$ & $4.9982 * *$ & $0.3417 * *$ \\
\hline$G_{i}-G_{j} @ 1 \%$ & $0.9089 * *$ & $0.4262 * *$ & $0.6508 * *$ & $2.4241 * *$ & $1.7870 * *$ & $7.1092 * *$ & $0.486 * *$ \\
\hline
\end{tabular}

* Significant at $\mathrm{P}=0.05$; ** Significant at $\mathrm{P}=0.01$; *** Significant at $\mathrm{P}=0.001$

Table.3 Association of genetic parameters with grain yield, its attributing traits and reaction to LWD infection in maize

\begin{tabular}{|c|c|c|}
\hline \multirow[t]{2}{*}{ Quantitative traits } & \multicolumn{2}{|c|}{ Correlation of } \\
\hline & $\begin{array}{c}\text { Parental gca effects } \\
\text { vs. } \\
\text { per se performance } \\
\text { of parents }\end{array}$ & $\begin{array}{c}\text { Sum of parental gca } \\
\text { effects } \\
\text { vs. } \\
\text { per se performance } \\
\text { of hybrids }\end{array}$ \\
\hline Ear length (cm) & 0.49 & $0.79 * *$ \\
\hline Ear circumference $(\mathrm{cm})$ & 0.16 & $0.73 * *$ \\
\hline Kernel row cob ${ }^{-1}$ & $0.76 * *$ & $0.62 * *$ \\
\hline Kernels row $^{-1}$ & 0.456 & $0.75^{* *}$ \\
\hline 100 grain weight (g) & 0.55 & $0.20 * *$ \\
\hline Grain yield plant $^{-1}(\mathrm{~g})$ & 0.19 & $0.62 * *$ \\
\hline Response to LWD infection & 0.54 & $0.52 * *$ \\
\hline
\end{tabular}




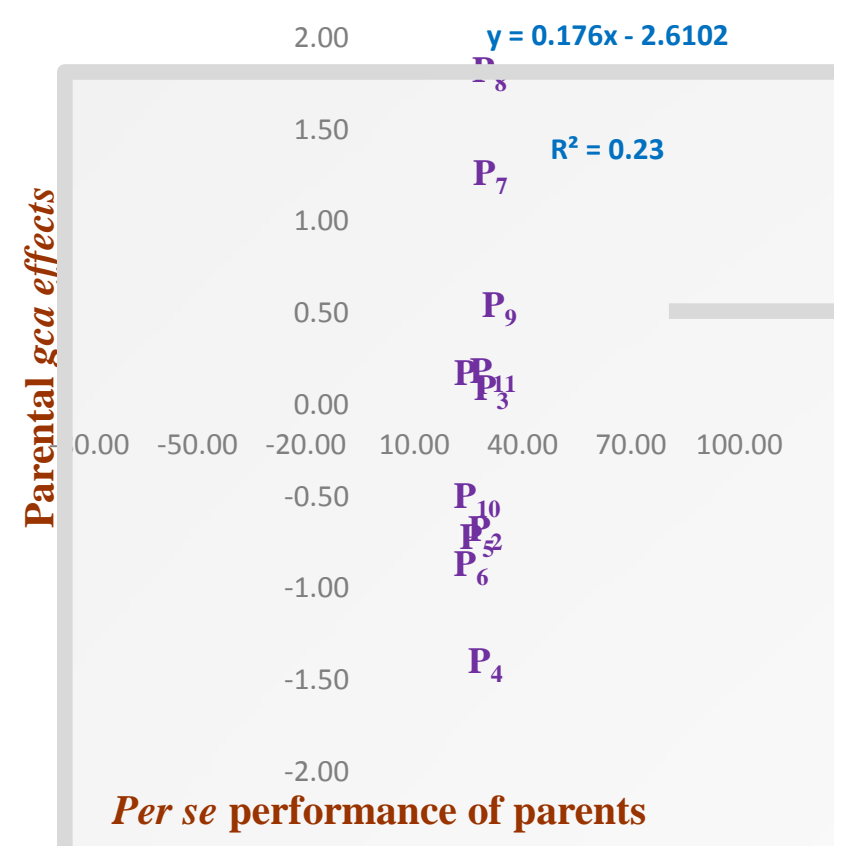

Fig.1 Correlation of per se performance of inbreds with their $g c a$ effects for ear length $(\mathrm{cm})$

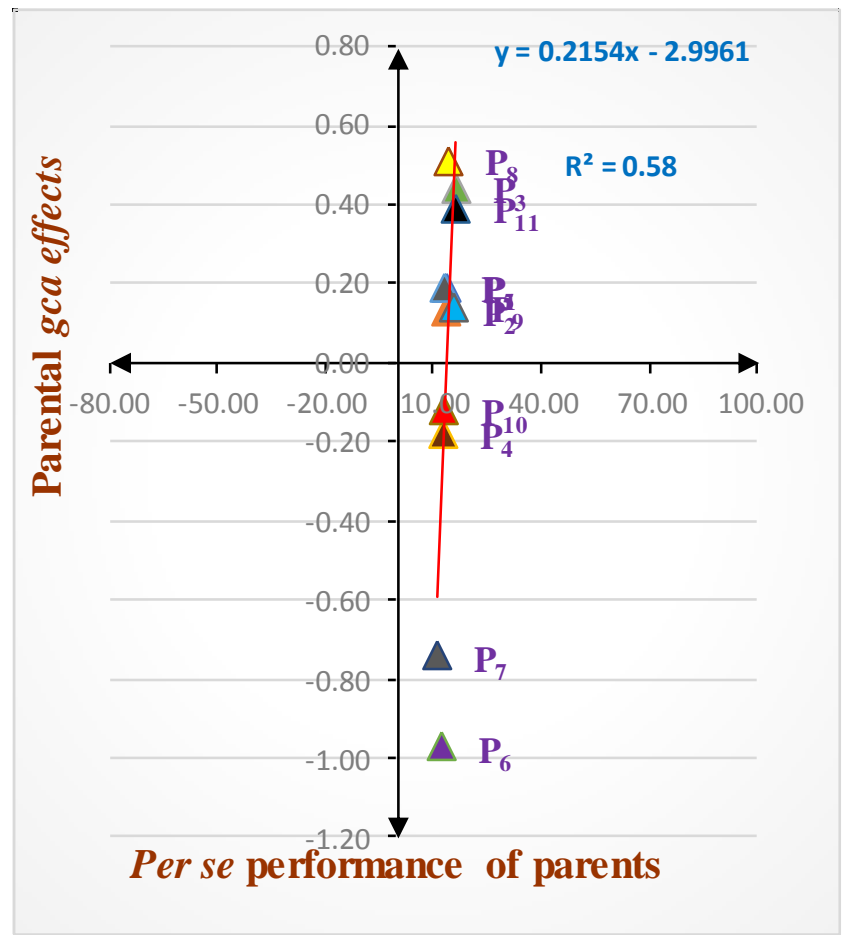

Fig.3 Correlation of per se performance of inbreds with their $g c a$ effects for kernel row $\operatorname{cob}^{-1}$

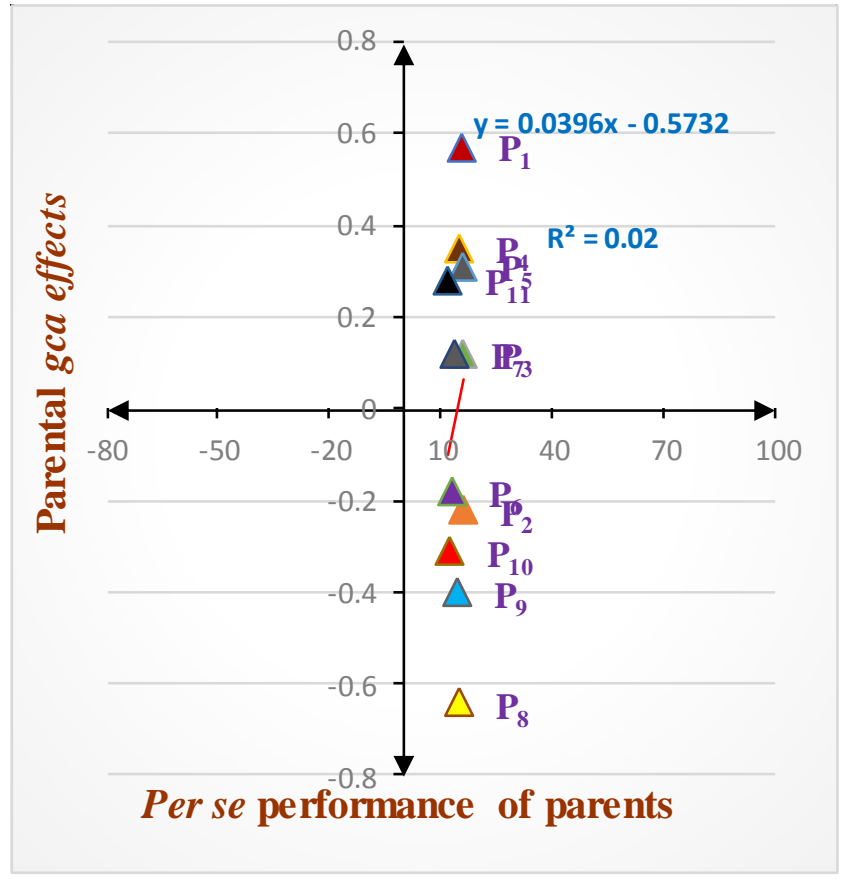

Fig.2 Correlation of per se performance of inbreds with their $g c a$ effects for ear circumference $(\mathrm{cm})$

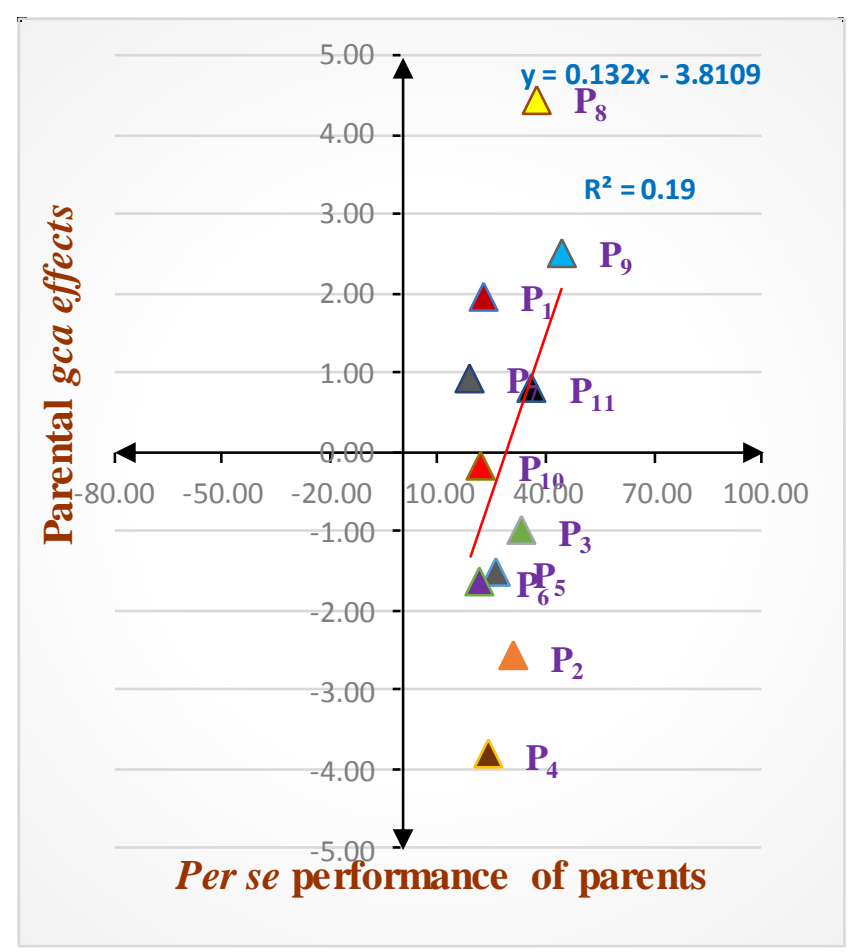

Fig.4 Correlation of per se performance of inbreds with their $g c a$ effects for kernels row ${ }^{-1}$ 


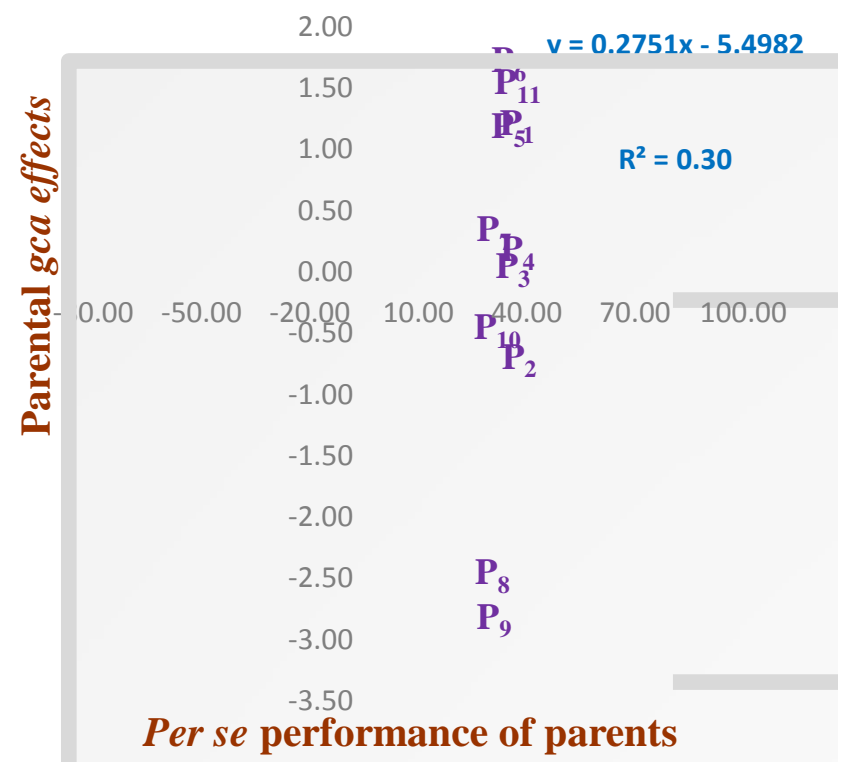

Fig.5 Correlation of per se performance of inbreds with their gca effects for 100 grain weight (g)

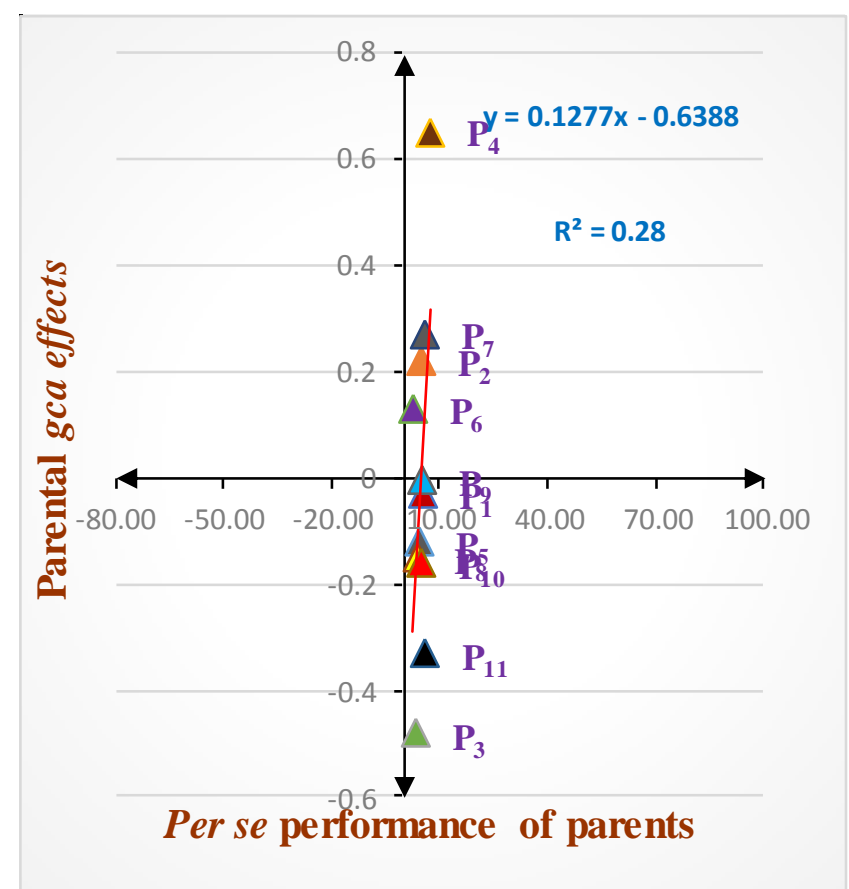

Fig.7 Correlation of per se performance of inbreds with their gca effects for response to LWD infection

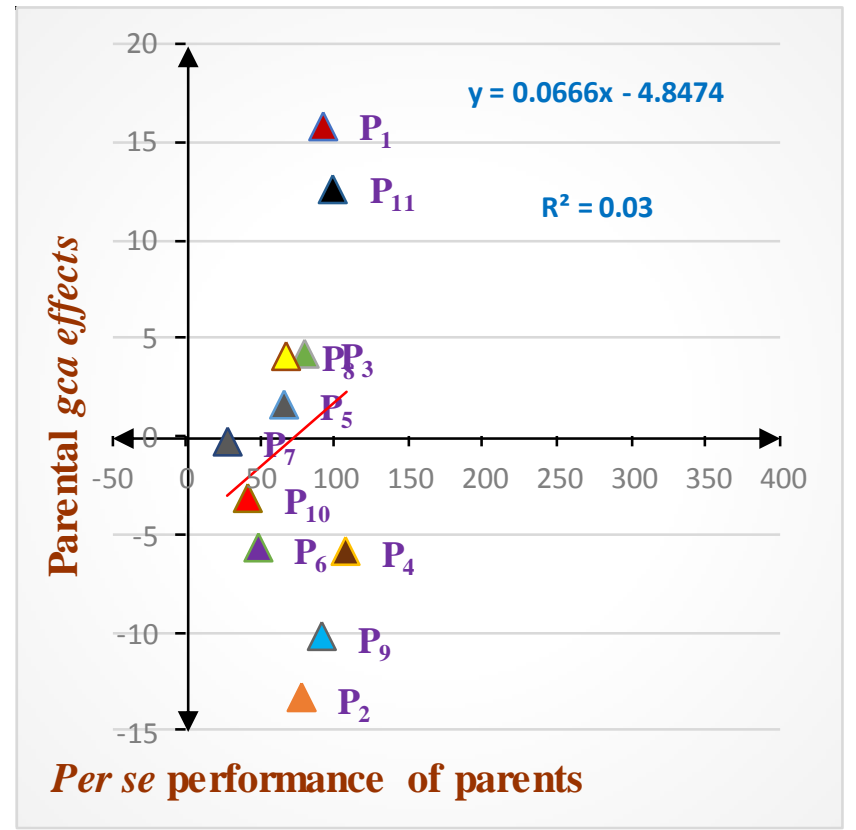

Fig.6 Correlation of per se performance of inbreds with their $g c a$ effects for grain yield plant ${ }^{-1}(\mathrm{~g})$

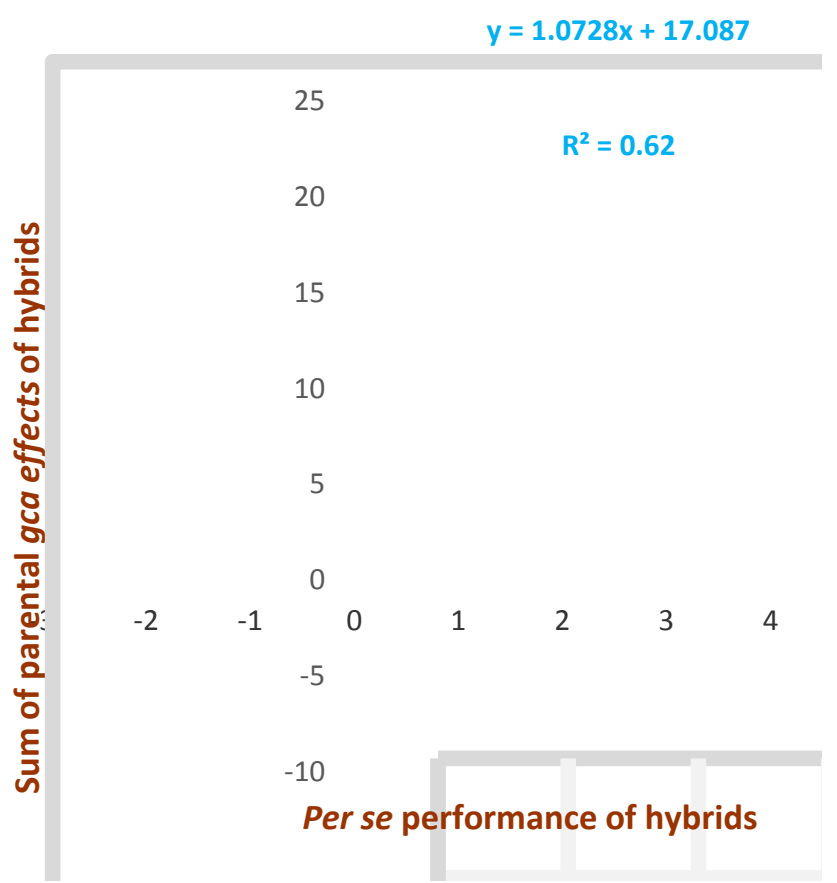

Fig.8 Correlation of hybrid per se performance with sum of parental $g c a$ effects for ear length $(\mathrm{cm})$ 


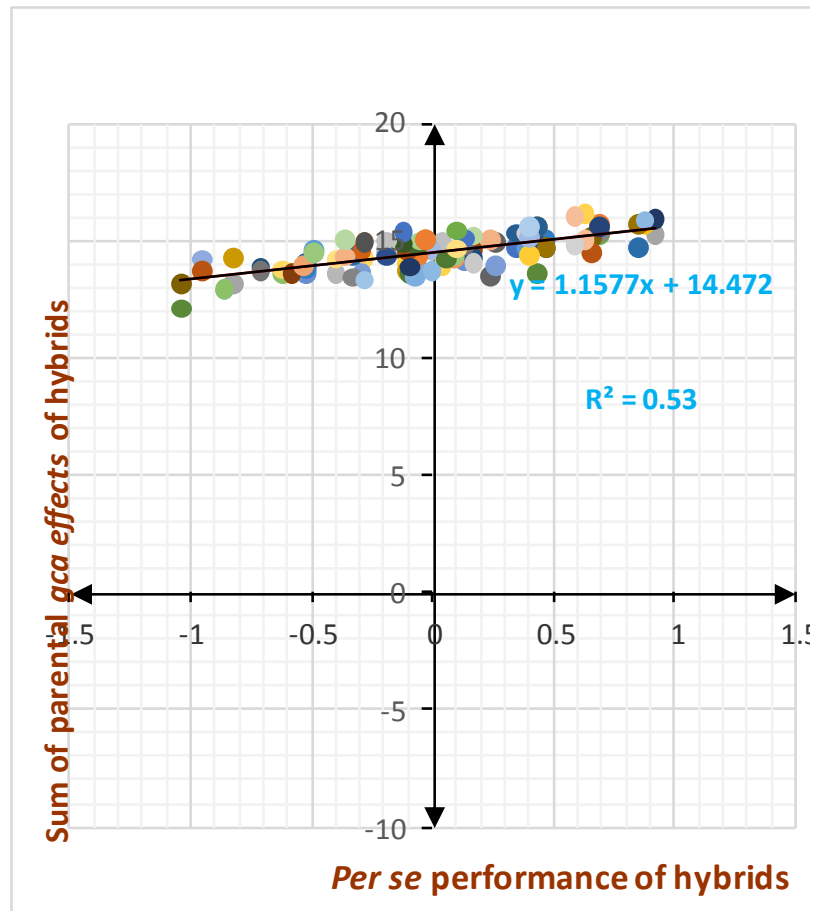

Fig.9 Correlation of hybrid per se performance with sum of parental $\mathrm{gca}$ effects for ear circumference $(\mathrm{cm})$

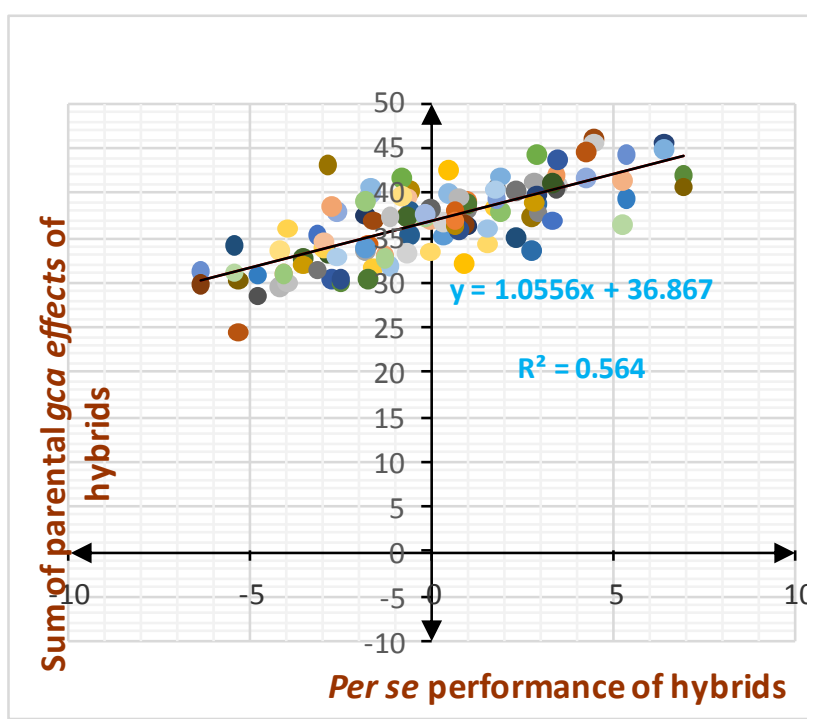

Fig.11 Correlation of hybrid per se performance with sum of parental gca effects for kernels row ${ }^{-1}$

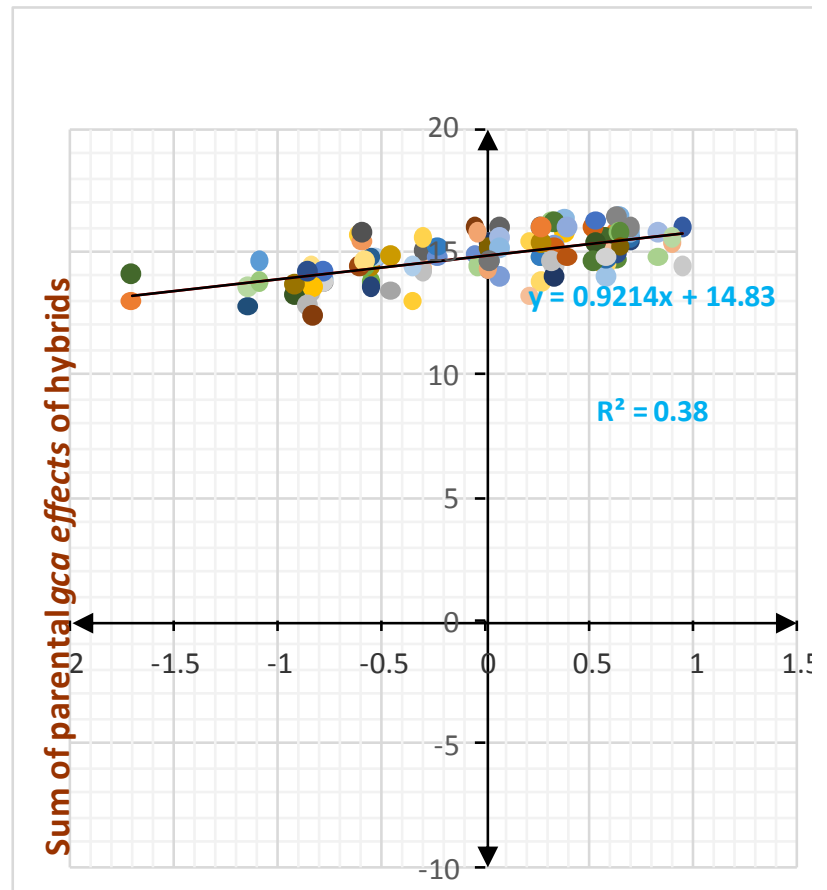

Per se performance of hybrids

Fig.10 Correlation of hybrid per se performance with sum of parental gca effects for kernel row cob ${ }^{-1}$

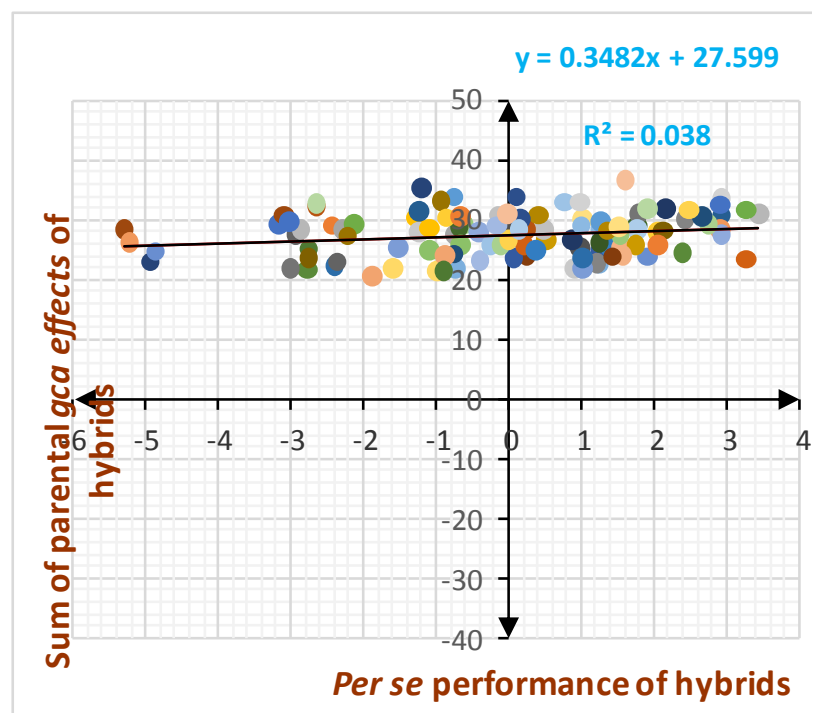

Fig.12 Correlation of hybrid per se performance with sum of parental gca effects for 100 grain weight $(\mathrm{g})$ 


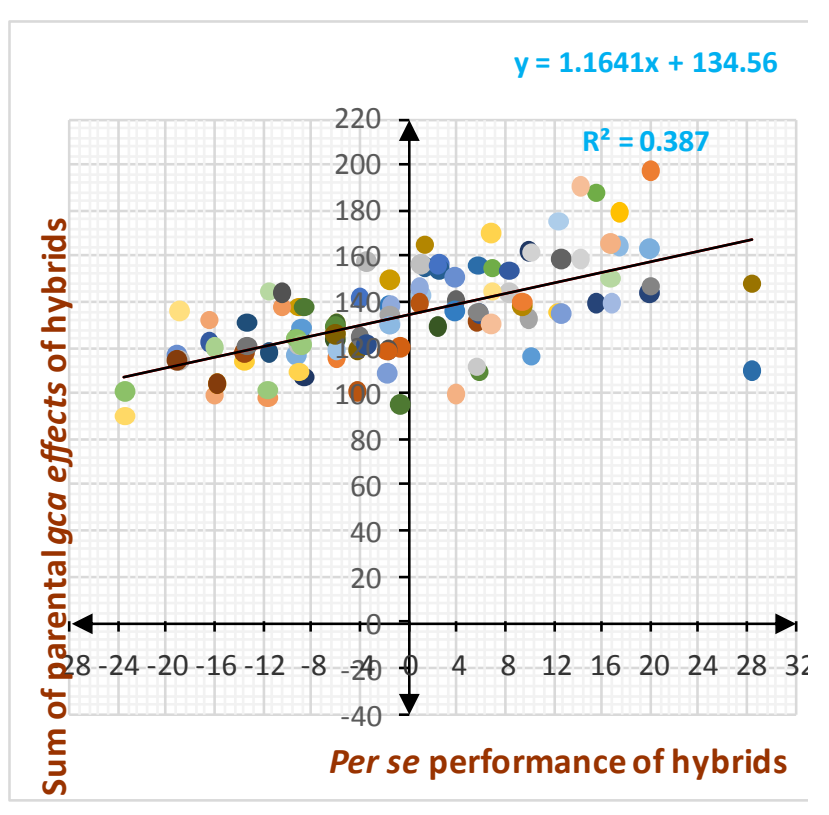

Fig.13 Correlation of hybrid per se performance with sum of parental gca effects for grain yield plant ${ }^{-1}(\mathrm{~g})$

\section{Relationship of gca effects of inbred lines with theirper se performance}

Significant positive but low magnitude of correlation between per se performance of the inbreds and their $\mathrm{gca}$ effects only for Kernel rows ear ${ }^{-1}$ (Figure 1-7 and Table 3), hence, suggested that per se performance of the lines is not a good indicator of their gca effects for any of the traits including LWD resistance.

The poor correlation between per se performance and gca effects of inbred line could be attributable to different sets of genes controlling per se performance and gca effects for target traits (Turner, 1953; AiZhi\& Zhang, 2012).

Significance of mean squares attributable to gca and sca (Table 1) provide evidence for the involvement of both additive genetic variance and dominance genetic variance for the expression of grain yield plant $^{-1}$, its attributing traits and LWD reaction.

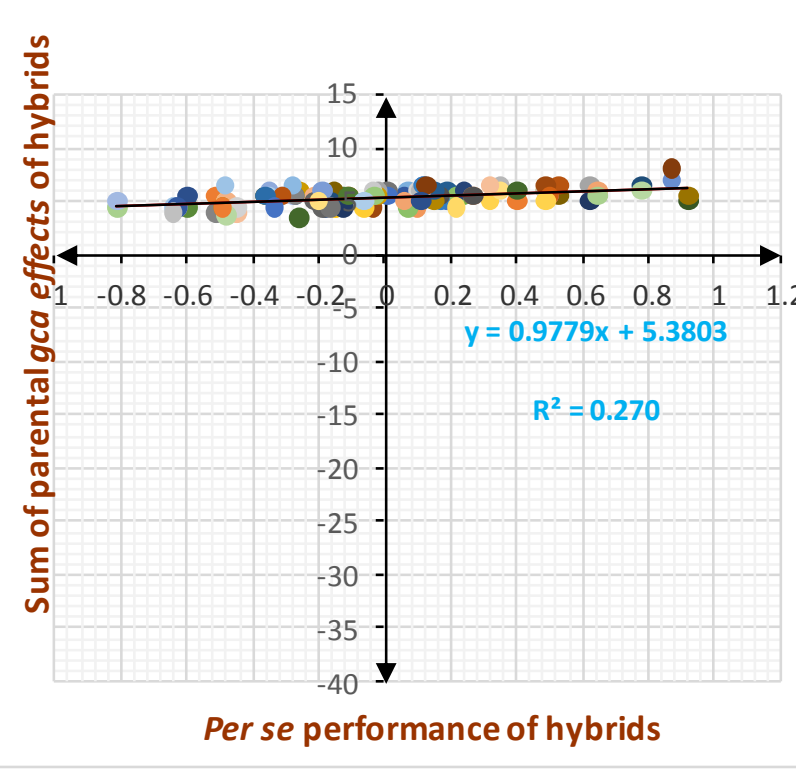

Fig.14 Correlation of hybrid per se performance with sum of parental gca effects for LWD Reaction

\section{Relationship of hybrid per se performance with sum of parental $g c a$ effects}

Relatively high magnitude of correlation between sum of the parental gca effects with hybrid per se performance for all the traits (Figure 7-12 and Table 3), suggested that sum of the parental gca effects retained fairly higher predictability of hybrid per se performance.

It helps to predict hybrids performance based on their parental gca which is attributable to additive effect genes (Falconer \& Mackay, 1996). Prediction of hybrid heterosis based on parental gca effects would save substantial resources as it enables the evaluation of only a few hybrids that are predicted to be most promising ones.

The utility of parental gca effects for predicting hybrid per se performance has also been reported by Schrag et al., (2009), Sowmya \& Gangappa (2018) and P. Roopa Sowjanya et al., (2019). 
From this study it is evident that the correlation between per se performance of hybrids and sum of parental gca effects will help in predicting the hybrids per se performance based on their parental gca effects for all the traits investigated including reaction to LWD infection, by selecting good inbreds which are having good gca effects for LWD reaction, grain yield and its component traits, we can expected to produce high yielding LWD resistant single cross hybrids. Hence, gca of parents can be used as a predictive tool for developing hybrids with superior per se, which in turn helps in reducing the use of input resources and enhances the breeding efficiency.

\section{References}

Ai-Zhi, L. V., Zhang, H., Zhang, Z.X., Tao, Y.S., Bing, Y. U. E. and Zheng, Y.L., 2012. Conversion of the statistical combining ability into a genetic concept. Journal of Integrative Agriculture, 11: 4352

Ali, F., Mareeya, M., Hidayatur, R., Muhammad, N., Sabina, S. and Yan, J., 2011. Heritability estimates for yield and related traits based on testcross progeny performance of resistant maize inbred lines. Journal of Food, Agriculture \& Environment, 9: 438-443.

Aruna, K., 2018. Identification of high yielding and late wilt resistant maize inbreds. M.Sc. (Agri.) Thesis, Univ. Agric. Sci., Bengaluru.

Bernardo, R., 2010. Breeding for Quantitative traits in Plants. Second Edition, Stemma press, Woodbury, Minnesota.

El-Hosary, A. A. A., 2014. Relative values of three different testers in evaluating combining ability of new maize inbred lines. International Journal of Plant Breeding and Genetics, 8(2): 57-65.

Falconer, D. S., Mackay, T. F. C., 1996. Introduction to Quantitative Genetics. Addison Wesley Longman Limited,
London.

Fasahat, P., Rajabi, A., Rad, J.M. and Derera, J., 2016. Principles and utilization of combining ability in plant breeding. Biom. Biostat. Int. J., 4: 1-24.

Griffing, O., 1956. Concept of general and specific combining ability in relation to diallel crossing systems. Australian journal of biological sciences, 9(4): 463493.

Hayman, B. I., 1954. The Theory and analysis of diallel crosses. Genetics, 39: 789-809.

Hosana, G. C., Alamerew, S., Tadesse, B. and Menamo, T., 2015. Test cross performance and combining ability of maize (Zea mays L.) inbred lines at Bako, Western Ethiopia. Global J. INC.(USA), 15(4): 1-24.

Kanagarasu, S., Nallathambi, G. and Ganesan, K.N., 2010. Combining ability analysis for yield and its component traits in maize (Zea mays L.). Electronic Journal of plant breeding, 1(4): 915-920.

RoopaSowjanya, P., Gangappa, E., Ramesh, S., 2019. Combining ability for grain yield and its component traits in maize (zea mays L.). Journal of Experimental Biology and Agricultural Sciences 7: 376 $-381$

Schrag, T. A., Frish, M., Dhillon, B. S. and Melchinger, A. E., 2009. Marker-based prediction of hybrid performance in maize single-crosses involving doubled haploids. Maydica, 54(2): 353-362.

Sowmya, H. H. and Gangappa, E., 2018. Testing early generation (F4) maize (Zea mays L.) inbred lines for general combining ability. Mysore Journal of Agricultural Sciences, 52(3): 560-565.

Sprague, G.F. and Tatum, L.A., 1942. General vs. specific combining ability in single crosses of corn. Agronomy Journal, 34(10): 923-932.

Turner, J. H., 1953. A Study of Heterosis In Upland Cotton and Combining Ability and Inbreeding Effects. Agronomy Journal, 45(10): 487-490. 


\section{How to cite this article:}

Mahesh Biradar, E. Gangappa, S. Ramesh, P. Roopa Sowjanya, N. C. Sunitha, Gazala Parveen, H. H. Sowmya, and Suma. K. 2020. Association Between GCA and Per Se Performance of Parents and Hybrids for Grain Yield, its Attributing Traits and Late Wilt Disease (Harpophora maydis) Resistance in Maize (Zea mays L.). Int.J.Curr.Microbiol.App.Sci. 9(03): 2560-2570. doi: https://doi.org/10.20546/ijcmas.2020.903.293 